\title{
Improving Skills to Manage Household Waste in Wonokromo Urban Village, Surabaya
}

\author{
Author \\ Dedy Kunhadi, Badriyah, Yayah Atmajawati \\ Correspondence \\ Universitas WR. Supratman Surabaya, Sekolah Tinggi Ilmu Ekonomi Indonesia (STIESIA) Surabaya \\ Email: kunhadi.unipra76@gmail.com
}

\begin{abstract}
Surabaya is one of the cities in Indonesia that has problems on garbage. In handling the garbage, the city government of Surabaya issued a large enough budget to transport the waste to the landfill (TPA). This can be reduced if the waste from the source can be managed properly. Lack of public awareness in RT. 019, RW. 04 Kelurahan Wonokromo Surabaya City in managing household waste, it can be seen from the community disposing of waste is not sorted and do not know how to recycle the waste. By recycling waste into compost, in addition to helping the government in reducing the waste can also green the environment with the resulting compost fertilizer. Community service is done to members of the PKK in RT. 019, RW. 04, Wonokromo urban village of Surabaya, and implemented on April 1 November 31, 2015. The method used in community service is counseling and training in managing household waste. The result of community service is that most PKK members can sort waste and manage their household waste into compost, and the community environment becomes green from the resulting compost.
\end{abstract}

Keywords: garbage, compost fertilizer, household waste, manage

Received: 01 November 2017. Accepted: 05 January 2018

\section{Introduction}

Every year, the population of Surabaya always increases. The increasing population of Surabaya City is not only influenced by the high birth rate, but the movement of the population from other regions into Surabaya City who want to try to find their job. Based on data from the Department of Population and Civil Registry (Dispendukcapil) until the end of August 2017 the population of Surabaya City as many as 3,057,766 people consisting of 1,526,583 men and 1,531,183 women (Zaenal, 2017).

With the increasing population of Surabaya City, it is correlated with the increasing amount of waste generated. The consumption pattern of the population of Surabaya City contributes to produce various types of waste. Based on data from the Department of Hygiene and Green Open Space (DKRTH), Surabaya recorded the amount of waste entering Benowo Disposal Site (TPA) in 2016 reaches 1,500 tons per day, by 2015 by 2,000 tons per day and 2014 by 1,400 tons per day (Amaluddin, 2017).

In the Law of the Republic of Indonesia Number 18 Year 2008 on waste management, mandates the need for changes in waste management based on the end-of-pipe approach, that is, garbage collected, transported and disposed of to the final waste processing site and replaced by a new paradigm in waste management, such as view waste as a resource that has economic value and can be utilized, for example, for energy, compost, fertilizer or for industrial raw materials.

Lack of public participation in managing household waste, so it can have an impact on the environment. The government needs to make clear, firm, and socialized rules to the community in protecting the environment (Rosmidah, 2016). Meanwhile, according to Cahyo Ismoyo, et al. (2015) explains that there is no change in community behavior in managing household waste, so the volume of waste will not decrease.

According to Ayu Fitriana and Oedojo Soedirham (2013), explained that poor waste management can cause:

1. Place breeding of insects and other disruptive animals, so it can cause various diseases such as diarrhea, cholera, and typhoid.

2. Incidence of air, water and soil contamination. Air pollution caused by garbage among others emits an unpleasant odor, and dusts toxic gases. 
While the contamination of water and soil caused by garbage, that is: can change of color and odor in river water, dissemination of chemicals and microorganisms that brought on when rain fall and soaked dangerous materials in soil so contaminate wells and water source.

\section{Problem Identification}

During this time the community in RT. 019, RW. 04 Wonokromo urban village of Surabaya in disposing of garbage does not know how to recycle garbage generated, so it can result Final Disposal (TPA) accumulate.

The old paradigm in managing household waste based on end of pipe has caused many problems, it is time to be replaced by new paradigm in managing waste, that is looking at waste as a resource of economic value and can be utilized (Tri Widayatno, et al., 2009).

Habits of people in disposing of garbage in any place or not doing the process of the waste itself, it can be a pile of garbage that will endanger the health of the surrounding community. Continuous waste dumps can lead to soil contamination, water pollution, disease sources, unpleasant odors, disturbing scenery (Halim, et al., 2016).

Government programs on orderly, smooth, and uniform waste management will not work without any change in the behavior of the community itself (Agus Ramon and Afriyanto, 2015). From the problems faced by the community in RT. 019, RW. 04 Wonokromo urban village of Surabaya, the target of this community service activity is Family Empowerment Program (PKK) members can sort household waste by type, and can know how to recycle household waste into compost. Household waste is divided into 2 by type, namely organic waste and non-organic waste. Non-organic waste from households can be collected individually or in groups and deposited into garbage banks that have been working with collectors of used goods. While household organic waste can be recycled into compost, so that the resulting compost fertilizer can green the surrounding environment.

Target in this community service activities include: 1). Assist the government in socializing the 3R program (Reduce, Reuse, Recycle), so that in year 2020 free of waste, 2). Environment of the surrounding community to be clean and free from disease sources, and 3). To keep the environment green and to produce compost fertilizer.

The steps taken by the community service team in improving the skills of managing household waste into compost can be seen in Figure 1.

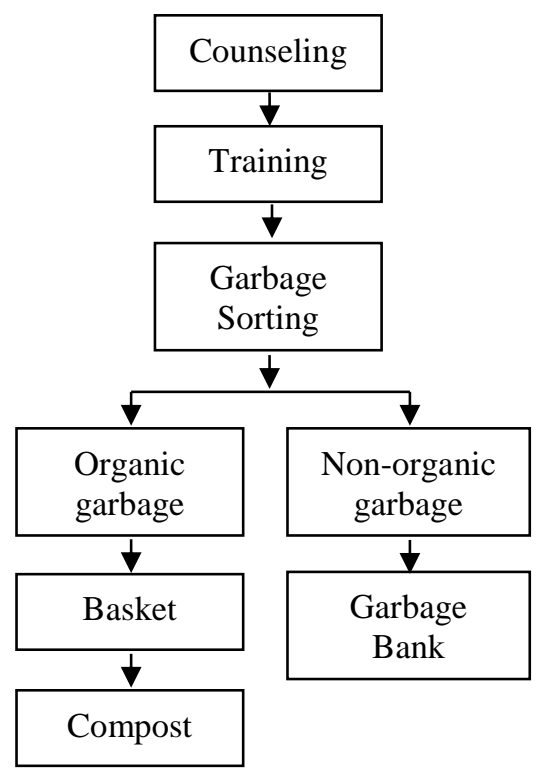

Figure 1 Steps in community engagement

\section{Method}

In solving the problems faced by PKK members in RT. 019, RW. 04 Wonokromo urban village of Surabaya, the community service team prepares a series of activities, namely counseling and training in improving the skills of managing household waste into compost. The activities are held for 8 months starting from April 1 to November 31, 2015 and the venue is held in RT. 019, RW. 04 Kelurahan Wonokromo Surabaya City.

Equipment and materials used in managing household waste into compost are: baskets, organic waste, compost that has been so (starters), shovels, knives, EM4, pads husk, used cardboard, porous black fabric. While how to make household waste into compost is:

1. Prepare the basket used for composting.

2. Insert the used carton to coat the basket.

3. The husk pad is inserted in the basket.

4. Enter the finished compost (as a starter) above the husk pads.

5. Enter the cut organic waste and mix EM4.

6. Close again with finished compost (as starter).

7. Cover with pads containing chaff.

8. Cover with a porous black cloth.

9. Cover with the basket cover. 
10.Place the basket in the shade.

Evaluation of community service activities undertaken by the Team starting from the aspect of activity planning, activity implementation aspect, and activity result aspect. From the aspect of these activities, then evaluated any deficiencies in the implementation, so as an input of community service activities that come.

\section{Results and Discussion}

The first step taken in this community service activity is to coordinate with the Chairman of PKK in RT. 019, RW. 04 Kelurahan Wonokromo Surabaya City in designing the implementation of extension activities and training how to manage household waste into compost. Community service activities agreed with the head of PKK RT. 019, RW. 04 Kelurahan Wonokromo Surabaya on April 10, 2015. Community service activities conducted in RT. 019, RW. 04 Kelurahan Wonokromo Surabaya responded positively, so that community service activities can run in accordance with the time set.

Implementation Community service activities in managing household waste into compost begins with the explanation of the theory of sorting waste by type and the process of composting the household scale. After members of PKK RT. 019, RW. 04 Kelurahan Wonokromo Surabaya is sufficient to understand, then practiced training in sorting waste by type and process of composting household scale by using basket.

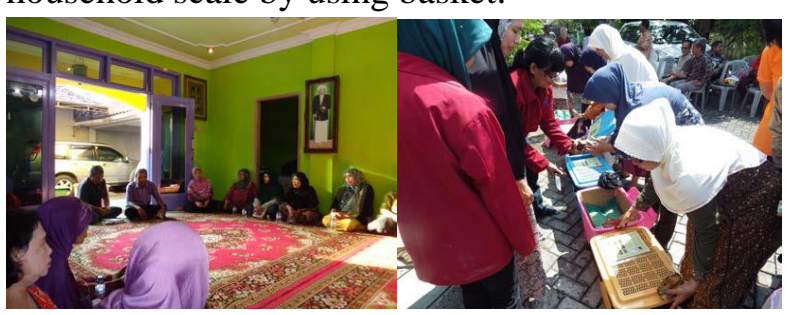

Figure 2. Counseling and Practice

Community service team performs monitoring every 1 week to see the process of making compost made by member of PKK RT. 019, RW. 04 Kelurahan Wonokromo Surabaya as expected or not. Approximately $80 \%$ of members of PKK RT. 019, RW. 04 Kelurahan Wonokromo Surabaya can make compost from household waste properly.

After the community service team conducts counseling and training in managing household waste provide questionnaires to PKK members. The results of the questionnaire from can be seen in table 1 below.

Table 1. Questionnaire Response

\begin{tabular}{|c|c|c|c|c|c|c|}
\hline \multirow{2}{*}{ No } & \multirow{2}{*}{ Question item } & \multicolumn{5}{|c|}{ Respondent } \\
\hline & & 1 & 2 & 3 & 4 & 5 \\
\hline 1 & $\begin{array}{l}\text { Understand the } \\
\text { extension material } \\
\text { delivered by the } \\
\text { resource person }\end{array}$ & 0 & 0 & 0 & 26 & 14 \\
\hline 2 & $\begin{array}{l}\text { Resource persons in } \\
\text { convey according to } \\
\text { the theme }\end{array}$ & 0 & 0 & 0 & 18 & 22 \\
\hline 3 & $\begin{array}{l}\text { The speakers in } \\
\text { delivering the } \\
\text { material are very } \\
\text { clear. }\end{array}$ & 0 & 0 & 0 & 21 & 19 \\
\hline 4 & $\begin{array}{l}\text { Knowledge of } \\
\text { resource persons in } \\
\text { solving problems }\end{array}$ & 0 & 0 & 0 & 27 & 13 \\
\hline 5 & $\begin{array}{l}\text { The implementation } \\
\text { of community } \\
\text { service runs } \\
\text { smoothly }\end{array}$ & 0 & 0 & 0 & 22 & 18 \\
\hline 6 & $\begin{array}{l}\text { Services during the } \\
\text { implementation of } \\
\text { community service }\end{array}$ & 0 & 0 & 0 & 29 & 11 \\
\hline 7 & $\begin{array}{l}\text { Community service } \\
\text { team is able to } \\
\text { maintain the } \\
\text { cleanliness of the } \\
\text { surrounding } \\
\text { environment. }\end{array}$ & 0 & 0 & 0 & 24 & 16 \\
\hline 8 & $\begin{array}{l}\text { Benefit from } \\
\text { community service } \\
\text { activities }\end{array}$ & 0 & 0 & 0 & 28 & 12 \\
\hline
\end{tabular}

Evaluation conducted in community service activities includes 3 aspects, namely: aspects of planning, implementation aspects, and aspects of the results. While the indicator of the success of the implementation of community service can be seen in table 2 below.

Table 2. Evaluation of Community Service Programs

\begin{tabular}{|c|c|c|}
\hline Aspect & Indicators & Results \\
\hline Planning & $\begin{array}{l}\text { Coordination of } \\
\text { team of } \\
\text { dedication and } \\
\text { partners in the } \\
\text { implementation. }\end{array}$ & $\begin{array}{l}\text { Implementation } \\
\text { of community } \\
\text { service in } \\
\text { accordance } \\
\text { with the } \\
\text { schedule. }\end{array}$ \\
\hline Implementation & $\begin{array}{l}\text { Prepare the tools } \\
\text { and materials } \\
\text { used in the } \\
\text { implementation. }\end{array}$ & $\begin{array}{l}\text { The tools and } \\
\text { materials used } \\
\text { are well } \\
\text { available. }\end{array}$ \\
\hline Results & $\begin{array}{l}\text { The devotion } \\
\text { team conducts } \\
\text { counseling and }\end{array}$ & $\begin{array}{l}\text { At least } 80 \% \text { of } \\
\text { participants } \\
\text { understand and }\end{array}$ \\
\hline
\end{tabular}


composting training

understand

what the

resource

described.

In the implementation of community service activities, community service team faces obstacles, namely:

1. Age factor, most of the age of PKK member over 55 years old so that difficulty in flipping through compost in basket by using scoop.

2. The busyness factor, most PKK members work, so do not have time to throw compost in the basket.

\section{References}

Agus Ramon dan Afriyanto. 2015. Karakteristik Penanganan Sampah Rumah Tangga di Kota Bengkulu. Jurnal Kesehatan Masyarakat Andalas, Vol. 10, No. 1, 24-31.

Amaluddin, "2016, Surabaya Hasilkan Sampah 1.500 Ton/Hari”, www.jatim.metrotvnews.com /peristiwa/ZkeWlVAN-2016-surabayahasilkan-sampah-1-500-ton-hari, tanggal akses 20 Desember 2017.

Ayu Fitriana dan Oedojo Soedirham. 2013. Perilaku Ibu Rumah Tangga Dalam Pengelolaan Sampah Di Desa Bluru Kidul Rw 11 Kecamatan Sidoarjo. Jurnal Promkes, Vol. 1, No. 2, 132137.

Cahyo Ismoyo, et al., 2015. Peningkatan Partisipasi Masyarakat Dalam Pengelolaan Sampah Rumah Tangga. Reformasi, Vol. 5, No. 1, 75 - 88.

Halim Dedy Perdana, Santoso Tri Hananto, Bandi, dan Sri Murni. 2016. Peningkatan Sarana Prasarana Pengelolaan Sampah Rumah Tangga Desa Doplang Kabupaten Boyolali. Jurnal Pengabdian Kepada Masyarakat (PKM), Volume 22 No. 4 Edisi Khusus SNEHPKM 2016, 1 - 9. http://jurnal.unimed.ac.id/2012/ index.php/jpkm/article/view/5735/5143.

Rosmidah Hasibuan. 2016. Analisis Dampak Limbah/Sampah Rumah Tangga Terhadap Pencemaran Lingkungan Hidup. Jurnal Ilmiah "Advokasi" Vol. 04. No. 01, 42 - 52.

Tri Widayatno, et al., 2009. Penyuluhan Pengolahan Limbah Pertanian Dan Sampah Rumah Tangga Di Desa Demangan Kecamatan Sambi Kabupaten Boyolali. WARTA, Vol .12, No.1, 69
- 75. https://publikasiilmiah.ums.ac.id/bitstream /handle/11617/1162/69-75.pdf?sequence=1.

Undang-Undang Republik Indonesia Nomor 18 Tahun 2008 Tentang Pengelolaan Sampah.

Zaenal Effendi, "Surabaya Kebut Pencocokan Jumlah Penduduk Hingga Akhir Tahun", www.news.detik.com/berita-jawa-timur/d3647897/surabaya-kebut-pencocokan-jumlahpenduduk-hingga-akhir-tahun, tanggal akses 20 Desember 2017. 